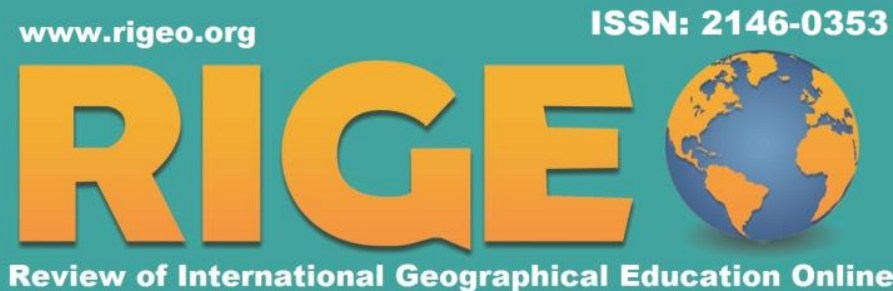

Review of International Geographical Education Online

(C)RIGEO Volume 8, Number 3, Winter 2018

Research Article

Copyright $\odot$ RIGEO 2018

To cite this article: Kaya, M. T.; Yazıcl, H. (2018). Self-Efficacy of the Social Studies Teachers in Using the Interactive Whiteboards. Review of International Geographical Education Online (RIGEO), 8(3), 601-612. Retrieved from http://www.rigeo.org/vol8no3/Number3winter/RIGEO-V8-N3-10.pdf

Submitted: June 01, 2018

Revised: December 4, 2018

Accepted: December 12, 2018

\title{
Self-Efficacy of the Social Studies Teachers in Using the Interactive Whiteboards*
}

\author{
Mehmet Tamer KAYA ${ }^{1}$ \\ Afyon Kocatepe University, Afyonkarahisar, TURKEY \\ Hakkı YAZICI ${ }^{2}$ \\ Afyon Kocatepe University, Afyonkarahisar, TURKEY
}

\begin{abstract}
The aim of this study is to analyse the self-efficacy of the social studies teachers in regard to the use of smart whiteboards. In the study the self-efficacy of the social studies teachers in regard to the use of smart boards was examined based on some variables (i.e., gender, age and receiving training on the use of information technologies). The study was designed according to the survey design and the participants were 101 social studies teachers working at public secondary schools in Afyonkarahisar province of Turkey. The data of the study were collected using the Self-Efficacy Scale in Using the Interactive Blackboard developed by Yalçınkaya and Özkan (2014). The data collected were analysed with the descriptive statistics, independent group's t Test and one-way analysis of variance. The findings indicate that the self efficacy of the social studies teachers participated in the study was at the level of "agree" suggesting that they perceived themselves competent in using the interactive blackboard. It was found that their self-efficacy in using the interactive blackboard did not vary based on the variables of gender and age, but prior training on information technologies had positive effects on their self-efficacy in using the interactive blackboard.
\end{abstract}

\section{Keywords}

Smart/Interactive whiteboard; Self-Efficacy; Social Studies Education

In our time it has become very important to reach the information in the shortest and fastest way. In line with this situation many projects in different countries are being

\footnotetext{
*This study has been derived from the doctoral thesis of the first author.

${ }^{1}$ Corresponding author: Research Assistant, Afyon Kocatepe University, Faculty of Education, Ahmer Necdet Sezer Campus, 03200,

Afyonkarahisar, Turkey, mtkaya[at]aku.edu.tr

${ }^{2}$ Prof. Dr., Afyon Kocatepe University, Faculty of Education, Ahmer Necdet Sezer Campus, 03200, Afyonkarahisar, Turkey,

hyazıcı[at]aku.edu.tr
} 
implemented to employ the information technologies in educational settings and to integrate such technologies into educational process. Previously some educational materials such as chalkboard, books and maps were employed in the educational process. However, these materials are now being replaced by information technologies. Through projects as mentioned above, schools have had high-level access to information and communication technologies, such as interactive boards, tablets, laptops, projectors, and software, Internet infrastructure and various equipment (Koçak, 2013; Falloon, 2015; MoNE, 2017; Pamuk, Çakır, Ergun, Yılmaz and Ayas, 2013). Such changes and developments in educational technologies have created new attitudes, new functions and roles for teachers and increased their importance in the teaching process. In order to meet the needs of the information societies and to prepare our students better for the future, it is necessary to educate them well on how they will learn, how they will think and how they will use the necessary educational technologies. Teachers' ability to perform their duties effectively in teaching processes depends on their competences. More qualified students can be educated as teachers' competencies increase (Gözütok, 1995; Mentiş Taş, 2004).

The use of technology in the education and learning process improves the quality of education, student attendance and persistence of knowledge. Therefore, both teachers and students should be competent in using educational technologies. Such competency makes it possible to easily learn and evaluate the information given in school and to utilize this new information gained in school life (Boyraz, 2008; Akkoyunlu, 2002). Educational technology has many positive effects such as supporting individual learning, increasing interest in the course and facilitating teaching (Lortoğlu, 2008). The use of technology in education helps students and teachers in the learning process, prioritizes the student and positively affects students' learning according to their individual learning styles. It also makes it possible to repeat the topics to be taught whenever it is necessary and to offer individual studying opportunities to students which may produce the desired level of student achievement. In addition, it contributes positively to students' thinking skills and helps students to learn by understanding and understanding instead of memorizing information (Taşlibeyaz, 2010; Atman, 2005).

When educational technologies are used, students can easily reach knowledge which improves learning. In order to increase the level of learning, educators should pay attention to the use of those learning and teaching materials that bring the students to the forefront while preparing the course materials. In order to realize an effective learning, it is necessary to use various software and hardware and to make information concrete. In addition, teachers should have a positive attitude towards technology due to the fact that it allows for using several teaching-learning activities and games. They should also have necessary knowledge and skills about the educational materials. Teachers should therefore be trained in the use of modern technologies in educational settings (Yalçınkaya and Özkan, 2014; Zengin, Kırılmazkaya and Keçeci, 2011; Cavas et. al., 2009).

One of the earliest examples of the use of technology for educational purposes was computer aided education. Following this approach the use of technology for educational purposes became much more widespread. Following the widespread use of various 
technological tools and materials in the classroom, at the beginning of the 1990s interactive whiteboards began to be used (Şad, 2012). Interactive or smart whiteboards are one of the educational equipment which include the functions of many different materials and tools, the course content covered addresses different senses of students and teachers may access various distinct sources through a single touch (Qirim, 2011; Erduran and Tataroğlu, 2009). Using the touch screen both teachers and students may intervene and make changes in course delivery and problem solving. Another point is that topics are made concrete through sounds and animations and emphasizing the significant sections (Lewin, Somekh and Steadman, 2008). Therefore, the smart whiteboards which support distinct techniques improve the motivation of the students and their attention and also, student achievement by making the lessons more enjoyable and interesting (Barak, 2007; Levy, 2002). In addition, it makes it possible to have Internet access to find further written and visual sources about the courses and for teachers to save the course notes for future uses. Teachers may use these saved notes with students who may use them later if they could not attend courses or if they want to repeat the course content (Starkings and Krause, 2008).

The importance of educational technologies has increased. In Turkey there are some initiatives to integrate technology into education. The FATİH Project (which is Turkish abbreviation of 'The Action for Increasing Opportunities and Improvement of Technology') initiated by the Ministry of National Education (MoNE) in Turkey increased the use of smart whiteboards at schools. On the other hand, the skills part of the education program for the social studies courses was expanded to include digital literacy and search skills using technological devices. One of seven learning domains for the social studies courses is stated as science, technology and society. In addition, one of the particular goals of the program is to make students recognize the development process of science and technology and its effects on social life and to consciously use the information and communication technologies.

Although there are many studies on the use of smart whiteboards, it is only in recent period that such studies have increased in Turkey. Most of the latter studies are generally about the views of the students about the smart whiteboards and the effects on students (Kefeli, 2013). There are not enough studies on teacher competency which is very important for the succesfull use of smart whiteboards in educational environments. (Yalçınkaya and Özkan, 2014; Doğan-Yılmaz, 2014; Kocaoğlu and Akgün, 2015; Betoncu, 2017). This study specifically attempts to fill the gap through the analysis of self-efficacy of social studies teachers in using smart whiteboards. Therefore, the aim of this study is to analyse the self-efficacy of the social studies teachers in regard to the use of smart whiteboards. In line with this aim, the study attempts to answer the following research questions:

1) What are the self-efficacy levels of social studies teachers in using the smart whiteboards? 
Kaya, M. T.; Yazıcı, H. (2018). Self-efficacy of the social studies teachers in using the interactive....

2) Does the self-efficacy level of social studies teachers in using the smart whiteboards significantly differ by gender?

3) Does the self-efficacy level of social studies teachers in using the smart whiteboards significantly differ by age?

4) Does the self-efficacy level of social studies teachers in using the smart whiteboards significantly differ by the factor of receiving or not receiving training on information technologies?

\section{Method}

The study which aims at analysing the self-efficacy of the social studies teachers in regard to the use of the smart whiteboards is designed based on the survey design which is part of descriptive research types. This model is a model where a group of the community is selected as a working group to describe the characteristics of a large community, such as a topic or event, or features of interest, skill, ability, attitude, etc. and where the data of the research are based on the answers of these participants (Fraenkel and Wallen, 2006). The individuals, objects or events to be analysed are described in their own conditions (Karasar, 2012).

\section{Participants}

The participants of the study were 101 social studies teachers working at public secondary schools in Afyonkarahisar province during the school year of 2016-2017. Of 101 participants 59 were female and 42 male. Some personal information about the participants is given in Tablo 1 .

Table 1

Personal Information about the Participants

\begin{tabular}{lcc}
\hline \multicolumn{1}{c}{ Gender } & n & \% \\
\hline Female & 59 & 58,4 \\
Male & 42 & 41,6 \\
\hline Age & & \\
\hline 25 and younger & 22 & 21,8 \\
$26-30$ & 29 & 28,7 \\
$31-35$ & 30 & 29,7 \\
36 and older & 20 & 19,8 \\
\hline Prior training on information & & \\
technologies & & \\
\hline Yes & 78 & 77,2 \\
No & 23 & 22,8 \\
\hline \multicolumn{1}{c}{ Total } & 101 & 100 \\
\hline
\end{tabular}

\section{Data Collection Tool}

The data of the study were collected using the Self-Efficacy Scale in Using the Interactive Blackboard developed by Yalçınkaya and Özkan (2014). The scale is consisted of 23 items and five factors. These factors are as follows: "use", "competency", "problems and solutions", "use in different settings" and "learning". The answers to the 
items are given on a 5-point likert type scale: completely agree (5), agree (4), no idea (3), disagree (2), and completely disagree (1). All items in the scale are positive statements. The original Cronbach alpha coefficient of the scale was reported to be 0.94 . In the current study the Cronbach alpha coefficient of the scale is found to be 0,97 .

\section{Data Collection and Data Analysis}

In analysing the self-efficacy of the participants in using the smart whiteboards the arithmetic mean and standard deviation values based on their scores from the SelfEfficacy Scale in Using the Interactive Blackboard. The t-test for independent groups and one-way analysis of variance were used to analyse whether or not gender, age and prior training on information technologies created any significant effect on their self-efficacy in using the smart whiteboards. The significance level was set at .05. A statistical package program was used in all statistical analyses.

\section{Findings}

\section{Findings on the Self-Efficacy Levels of the Social Studies Teachers in Using Smart Whiteboards}

The scores of the social studies teachers participated in the study from the scale of the self-efficacy in using the smart whiteboards were analyzed. In the analysis the arithmetic means of their scores from the scale was employed. The results of the analysis are given in Table 2.

\section{Table 2}

Results of the Participants' Scores from the Scale of the Self-Efficacy in Using the Smart Whiteboards

\begin{tabular}{lccccc}
\hline $\begin{array}{c}\text { Scale of the self-efficacy } \\
\text { in using the smart } \\
\text { whiteboards }\end{array}$ & $\mathbf{N}$ & $\mathbf{X}$ & Sd & Min. & Max. \\
\hline General & 101 & 3,754 & 0,811 & 1,480 & 4,960 \\
\hline Use & 101 & 3,770 & 0,867 & 1,400 & 5,000 \\
\hline Competency & 101 & 3,726 & 0,886 & 1,000 & 5,000 \\
\hline Problems and solutions & 101 & 3,795 & 0,836 & 1,330 & 5,000 \\
\hline Use in different settings & 101 & 3,670 & 0,964 & 1,000 & 5,000 \\
\hline Learning & 101 & 3,786 & 0,890 & 1,000 & 5,000 \\
\hline
\end{tabular}

As can be seen in Table 2 the mean self-efficacy score of the participants in regard to the use of smart whiteboards is 3.754. Therefore, the self efficacy of the social studies teachers participated in the study was at the level of "agree" suggesting that they perceived themselves competent in using the interactive blackboard. The mean scores for the dimensions of the scale are found to range between 3,795 and 3,670. The lowest mean score was for the dimension of the using smart whiteboards in different settings $(\mathrm{X}=3,670)$. The highest mean score is found for the dimension of "problems and solutions" $(\mathrm{X}=3,795)$. 
Kaya, M. T.; Yazıсı, H. (2018). Self-efficacy of the social studies teachers in using the interactive....

\section{Findings on the Self-Efficacy Levels of the Social Studies Teachers in Using Smart Whiteboards by Gender}

The effects of gender on the self-efficiacy mean scores of the participants in using the smart whiteboards were analysed through the t-test for independent samples. The results of the analysis are given in Table 3. More specifically, it shows the mean scores of the participants based on gender for both the scale as a whole and for the dimensions of the scale.

Table 3

Results of the Participants' Scores from the Scale of the Self-Efficacy in Using the Smart Whiteboards by Gender

\begin{tabular}{|c|c|c|c|c|c|c|}
\hline $\begin{array}{l}\text { Scale of the self- } \\
\text { efficacy in using the } \\
\text { smart whiteboards }\end{array}$ & Group & $\mathbf{N}$ & $X$ & Sd & $\mathbf{t}$ & $\mathbf{p}$ \\
\hline \multirow{2}{*}{ General } & Female & 59 & 3,643 & 0,823 & \multirow{2}{*}{$-1,642$} & \multirow{2}{*}{0,104} \\
\hline & Male & 42 & 3,910 & 0,777 & & \\
\hline \multirow{2}{*}{ Use } & Female & 59 & 3,654 & 0,867 & \multirow{2}{*}{$-1,606$} & \multirow{2}{*}{0,111} \\
\hline & Male & 42 & 3,933 & 0,852 & & \\
\hline \multirow{2}{*}{ Competency } & Female & 59 & 3,610 & 0,845 & \multirow{2}{*}{$-1,570$} & \multirow{2}{*}{0,120} \\
\hline & Male & 42 & 3,889 & 0,926 & & \\
\hline \multirow{2}{*}{ Problems and solutions } & Female & 59 & 3,706 & 0,873 & \multirow{2}{*}{$-1,274$} & \multirow{2}{*}{0,206} \\
\hline & Male & 42 & 3,921 & 0,774 & & \\
\hline \multirow{2}{*}{ Use in different settings } & Female & 59 & 3,492 & 1,018 & \multirow{2}{*}{$-2,248$} & \multirow{2}{*}{0,027} \\
\hline & Male & 42 & 3,921 & 0,832 & & \\
\hline \multirow{2}{*}{ Learning } & Female & 59 & 3,718 & 0,868 & \multirow{2}{*}{$-0,909$} & \multirow{2}{*}{0,366} \\
\hline & Male & 42 & 3,881 & 0,922 & & \\
\hline
\end{tabular}

Table 3 indicates that the self-efficacy mean scores of the female participants in using the smart whiteboards $(\mathrm{X} 59=3,643)$ is lower than those of the male participants $(\mathrm{X} 42=3,910)$. However, it is found that this difference is not statistically significant. Therefore, it can be argued that the self-efficacy mean scores of the participants in using the smart whiteboards do not differ by gender $[t(-1,642)=0,104, p>.05]$ and that gender is not a significant variable in terms of the self-efficacy in using the smart whiteboards.

The same result was also found for the dimensions: Use $[\mathrm{t}(-1,606)=0,111, \mathrm{p}>.05]$, competency $[\mathrm{t}(-1,570)=0,120, \mathrm{p}>.05]$, problems and solutions $[\mathrm{t}-(1,274)=0,206, \mathrm{p}>.05]$ and learning $[t(-0,909)=0,366, p>.05]$. In other words, the mean scores for these dimensions are found not to be significantly affected by gender. However, the mean score of the male participants for the dimension of using the smart whiteboards in different setting $(X 42=3,921)$ is higher than the female participants $(X 59=3,492)$. This difference is found to be statistically significant $[\mathrm{t}(-2,248)=0,027, \mathrm{p}<.05]$. On the other hand, the self-efficacy levels of both male and female participants are at "agree" level. 


\section{Findings on the Self-Efficacy Levels of The Social Studies Teachers in Using Smart Whiteboards By Age}

The effects of age on the self-efficiacy mean scores of the participants in using the smart whiteboards were analysed through the one-way analysis of variance. The results of the analysis are given in Table 4.

Table 4

Results of the Participants' Scores from the Scale of the Self-Efficacy in Using the Smart Whiteboards by Age

\begin{tabular}{|c|c|c|c|c|c|c|}
\hline $\begin{array}{l}\text { Scale of the self- } \\
\text { efficacy in using the } \\
\text { smart whiteboards }\end{array}$ & Group & $\mathbf{N}$ & $\mathrm{X}$ & Sd & $\mathbf{F}$ & $\mathbf{p}$ \\
\hline \multirow{4}{*}{ General } & 25 and younger & 22 & 3,818 & 0,521 & & \multirow{4}{*}{0,661} \\
\hline & $26-30$ & 29 & 3,846 & 0,856 & & \\
\hline & $31-35$ & 30 & 3,746 & 0,857 & 0,532 & \\
\hline & 36 and older & 20 & 3,563 & 0,951 & & \\
\hline \multirow{4}{*}{ Use } & 25 and younger & 22 & 3,855 & 0,691 & & \multirow{4}{*}{0,866} \\
\hline & $26-30$ & 29 & 3,752 & 0,911 & & \\
\hline & $31-35$ & 30 & 3,813 & 0,879 & J,243 & \\
\hline & 36 and older & 20 & 3,640 & 1,000 & & \\
\hline \multirow{4}{*}{ Competency } & 25 and younger & 22 & 3,788 & 0,722 & & \multirow{4}{*}{0,851} \\
\hline & $26-30$ & 29 & 3,810 & 0,962 & & \\
\hline & $31-35$ & 30 & 3,678 & 0,894 & 0,265 & \\
\hline & 36 and older & 20 & 3,608 & 0,966 & & \\
\hline \multirow{4}{*}{ Problems and solutions } & 25 and younger & 22 & 3,977 & 0,607 & \multirow{4}{*}{1,428} & \multirow{4}{*}{0,239} \\
\hline & $26-30$ & 29 & 3,914 & 0,845 & & \\
\hline & $31-35$ & 30 & 3,744 & 0,853 & & \\
\hline & 36 and older & 20 & 3,500 & 0,978 & & \\
\hline \multirow{4}{*}{$\begin{array}{l}\text { Use in different } \\
\text { settings }\end{array}$} & 25 and younger & 22 & 3,652 & 0,488 & \multirow{4}{*}{1,024} & \multirow{4}{*}{0,386} \\
\hline & $26-30$ & 29 & 3,874 & 0,998 & & \\
\hline & $31-35$ & 30 & 3,678 & 1,070 & & \\
\hline & 36 and older & 20 & 3,383 & 1,125 & & \\
\hline \multirow{4}{*}{ Learning } & 25 and younger & 22 & 3,667 & 0,823 & \multirow{4}{*}{0,505} & \multirow{4}{*}{0,680} \\
\hline & $26-30$ & 29 & 3,908 & 0,890 & & \\
\hline & $31-35$ & 30 & 3,844 & 0,852 & & \\
\hline & 36 and older & 20 & 3,650 & 1,040 & & \\
\hline
\end{tabular}

As can be seen in Table 4 the mean self-efficacy scores of the participants based on age groupings range between 3,846 and 3,563. The lowest mean self-efficacy score was found for the group of 36 and older age. However, it is found that the differences in the mean self-efficacy scores of the participants based on age groupings are not statistically significant for the scale and its dimensions $(\mathrm{p}>0.05)$. 
Kaya, M. T.; Yazıcı, H. (2018). Self-efficacy of the social studies teachers in using the interactive....

\section{Findings on the Self-Efficacy Levels of the Social Studies Teachers in Using Smart Whiteboards Based On Prior Education on Communication Technologies}

The effects of prior training on information technologies on the self-efficiacy mean scores of the participants in using the smart whiteboards were analysed through the t-test for independent samples. The results of the analysis are given in Table 5.

Table 5

Results of the Participants' Scores from the Scale of the Self-Efficacy in Using the Smart Whiteboards Based on Prior Education on Communication Technologies

\begin{tabular}{|c|c|c|c|c|c|c|}
\hline $\begin{array}{l}\text { Scale of the self-efficacy } \\
\text { in using the smart } \\
\text { whiteboards }\end{array}$ & Group & $\mathbf{N}$ & $\mathrm{X}$ & Ss & $\mathbf{t}$ & $\mathbf{p}$ \\
\hline \multirow{2}{*}{ General } & Yes & 78 & 3,858 & 0,747 & \multirow{2}{*}{2,422} & \multirow{2}{*}{0,017} \\
\hline & No & 23 & 3,403 & 0,934 & & \\
\hline \multirow{2}{*}{ Use } & Yes & 78 & 3,823 & 0,831 & \multirow{2}{*}{1,128} & \multirow{2}{*}{0,262} \\
\hline & No & 23 & 3,591 & 0,981 & & \\
\hline \multirow{2}{*}{ Competency } & Yes & 78 & 3,846 & 0,798 & \multirow{2}{*}{2,580} & \multirow{2}{*}{0,011} \\
\hline & No & 23 & 3,319 & 1,055 & & \\
\hline \multirow{2}{*}{ Problems and solutions } & Yes & 78 & 3,927 & 0,755 & \multirow{2}{*}{3,038} & \multirow{2}{*}{0,003} \\
\hline & No & 23 & 3,348 & 0,956 & & \\
\hline \multirow{2}{*}{ Use in different settings } & Yes & 78 & 3,774 & 0,945 & \multirow{2}{*}{2,017} & \multirow{2}{*}{0,046} \\
\hline & No & 23 & 3,319 & 0,967 & & \\
\hline \multirow{2}{*}{ Learning } & Yes & 78 & 3,885 & 0,802 & \multirow{2}{*}{2,096} & \multirow{2}{*}{0,087} \\
\hline & No & 23 & 3,449 & 1,095 & & \\
\hline
\end{tabular}

Table 5 indicates that the mean self-efficacy scores of the participants who received training on information technologies $(X 78=3,858)$ are much higher than those of the participants who did not receive such an education $(X 23=3,403)$. It was found that this difference is statistically significant $[t(2,422)=0,017, \mathrm{p}<.05]$. Therefore, it is possible to argue that prior training is one of the significant factors in terms of the self-efficacy in using the smart whiteboards. In addition, the mean scores of the following dimensions are found to be significantly affected by the prior training on information technologies: competency $[\mathrm{t}(2,580)=0,011, \mathrm{p}<.05]$, problems and solutions $[\mathrm{t}(3,038)=0,003, \mathrm{p}<.05]$ and the use of the smart whiteboards in different settings [t $(2,017)=0,046, \mathrm{p}<.05]$. However, the mean scores for the following dimensions are found not to be affected by the prior education on communication technologies: Use $[\mathrm{t}(1,128)=0,262, \mathrm{p}>.05]$ and learning $[\mathrm{t}(2,096)=0,087, \mathrm{p}>.05]$.

\section{Conclusions and Discussion}

The study examined the self-efficacy of the social studies teachers in regard to the use of smart whiteboards. The findings indicate that the self efficacy of the social studies teachers participated in the study was at the level of "agree" suggesting that they perceived themselves competent in using the interactive blackboard. This findings is 
similar to those found in the studies by Akkoyunlu, Orhan and Umay (2005), Yalçınkaya and Özkan (2014), and Doğan-Yılmaz (2014). Yalçınkaya and Özkan (2014) also found that the self efficacy of the participants was at the level of "agree" suggesting that they perceived themselves competent in using the interactive blackboard. Similarly, DoğanY1lmaz (2014) found that the self efficacy perceptions of the secondary school teachers participated in the study were at the medium level. Therefore, they perceived themselves generally compenent in using the smart whiteboards. In addition, Orhan and Umay (2005) concluded that pre-service computer education teachers had very high levels of selfefficacy in using the smart whiteboards.

The self-efficacy mean scores of the female participants in using the smart whiteboards $(\mathrm{X} 59=3,643)$ is lower than those of the male participants $(\mathrm{X} 42=3,910)$. However, it is found that this difference is not statistically significant. This finding is similar to the previous findings reported by Doğan-Y1lmaz (2014), Kocaoğlu (2013) and Şensoy (2004). Doğan-Y1lmaz (2014) found that the there was no significant differences between the mean self-efficacy scores of male and female secondary school teachers. Similarly, Kocaoğlu (2013) concluded that there was no significant differences between the mean self-efficacy scores of male and female high school teachers. In addition, Şensoy (2004) argued that self-efficacy of the teachers in relation to computer use did not significantly differ by gender. However, Yalçınkaya (2013) found that the self-efficacy of the male teachers in using interactive whiteboards was much higher than that of the female teachers.

The mean self-efficacy scores of the participants based on age groupings range between 3,846 and 3,563. However, it is found that the differences in the mean selfefficacy scores of the participants based on age groupings are not statistically significant for the scale and its dimensions. This finding is similar to those reported in the studies by Doğan-Y1lmaz (2014) and Koçak (2013). Doğan-Yılmaz (2014) found that there was no significant differences between the mean self-efficacy scores of younger and older secondary school teachers. Similarly, Koçak (2013) concluded that there was no significant correlation between teachers' age and their attitudes. However, Yalçınkaya (2013) argued that there was a significant correlation between the self-efficacy of secondary school teachers in using the interactive whiteboards and their age.

The mean self-efficacy scores of the participants who received training on information technologies $(\mathrm{X} 78=3,858)$ are much higher than those of the participants who did not receive such training $(X 23=3,403)$. It was found that this difference is statistically significant. The findings reported by Doğan-Y1lmaz (2014) were similar to the findings of the present research. More specifically, Doğan-Y1lmaz (2014) found that the selfefficacy of the secondary school teachers in regard to the use of interactive whiteboards improved after they attended in-service traning activities on the use of the communication or educational technologies. However, Sağlam (2007) found that prior education on communication technology did not have a significant effect on the participants' selfefficacy in using it in educational settings. 
Kaya, M. T.; Yazıcı, H. (2018). Self-efficacy of the social studies teachers in using the interactive....

Based on the findings of the research, the following suggestions have been made:

1. This study is based on a sample of secondary school teachers. Similar studies can be conducted with teachers working at the high school and higher education levels.

2. In-service trainings may be organized concerning the use of the smart boards.

3. Materials and educational software can be developed for teachers from different educational levels.

4. Teacher training programs may include courses about the use of smart whiteboards.

\section{References}

Akkoyunlu, B., Orhan, F. \& Umay, A. (2005). Bilgisayar öğretmenleri için "bilgisayar öğretmenliği öz yeterlik ölçeği’” geliştirme çabası. Hacettepe Üniversitesi Eğitim Fakültesi Dergisi, 29, 1-8.

Akkoyunlu, B. (2002). Öğretmenlerin internet kullanımı ve bu konudaki görüşleri. Hacettepe Üniversitesi Eğitim Fakültesi Dergisi, 22(1), 1-8.

Atman, Ç. (2005). Matematik öğretmenlerinin bilgisayar kullanımna ilişkin yeterlilikleri. Yayımlanmamış Yüksek Lisans Tezi. Anadolu Üniversitesi, Eskişehir.

Barak, M. (2007). Transition from traditional to ICT-enhanced learning environments in undergraduate chemistry courses. Computers \&Education, 48, 30-43.

Betoncu, O. (2017). KKTC'de etkileşimli tahta kullanan ögretmenlerin tutum ve öz yeterlik algılarının belirlenmesi. Yayımlanmamış Yüksek Lisans Tezi. Yakın Doğu Üniversitesi, Lefkoşa.

Boyraz, Z. (2008). Türk eğitim sisteminde ĕgitim teknolojisinin ĕgitim - öğretim kalitesine etkisi. Yayımlanmamış Yüksek Lisans Tezi. Sosyal Bilimleri Enstitüsü, Beykent Üniversitesi, İstanbul.

Cavas, B., Cavas P., Karaoğlan B. \& Kışla T. (2009). A study on science teachers' attitudes toward information and communication technologies in education. The Turkish Online Journal of Educational Technology (Tojet), 8(2), 20-32.

Doğan-Yılmaz, G. (2014). Öğretmenlerin etkileşimli tahta kullanımına yönelik öz-yeterlik algıları ve kaygı düzeylerinin incelenmesi: Niğde ili örneği. Yayımlanmamış Yüksek Lisans Tezi, Gazi Üniversitesi, Ankara.

Erduran, A. \& Tataroğlu, B. (2009). Eğitimde akıllı tahta kullanımına ilişkin fen ve matematik öğretmen görüşlerinin karşılaştııılması, International Technology Conferance (IETC), Ankara.

Falloon, G. (2015). What's the difference? Learning collaboratively using iPads in conventional classrooms. Computers \& Education, 84, 62-77.

Fraenkel, J.R. \& Wallen, N.E. (2006). How to design and evaluate research in education. New York: McGraw-Hill.

Gözütok, F. D. (1995). Öğretmenlerin demokratik tutumları. Ankara: Türk Demokrasi Vakfı Yayınları. 
Karasar, N. (2012). Bilimsel araştırma yöntemi. Ankara. Ankara, Nobel Yayın Dağıtım.

Kefeli, P. (2013) Öğretim sürecinde etkileşimli tahta kullanımına yönelik geliştirilen bir hizmet içi eğitim kursu ve yansımaları. Yayımlanmamış Yüksek Lisans Tezi, Karadeniz Teknik Üniversitesi, Trabzon.

Kocaoğlu, B. Ü. \& Akgün, Ö. E. (2015). Lise öğretmenlerinin fatih projesi teknolojilerini kullanmaya yönelik öz yeterlik inançları. Uluslararası Ĕgitim Bilimleri Dergisi, 2(4), 259279.

Kocaoğlu, B. Ü. (2013). Lise ögretmenlerinin fatih projesi teknolojilerini kullanmaya yönelik özyeterlik inançları: Kayseri ili örneği. Yayımlanmamış Yüksek Lisans Tezi, Sakarya Üniversitesi, Sakarya.

Koçak, Ö. (2013). Fatih projesi kapsamındaki LCD panel etkileşimli tahta uygulamalarına yönelik ögretmen tutumları: Erzincan ili örneği. Yayımlanmamış Yüksek Lisans Tezi, Atatürk Üniversitesi, Erzurum.

Levy, P. (2002). Interactive whiteboards in learning and teaching in two sheffield schools: A developmental study. University of Sheffield.

Lewin, C., Somekh, B. \& Steadman, S. (2008). Embedding interactive whiteboards in teaching and learning: the process of change in pedagogic, Education and Information Technologies, 13, 291-303.

Lortoğlu, A. (2008). Sinı öğretmenlerinin yapılandırmacı ögretġm programı kapsamında, eğitim teknolojisi uygulamalarında karşılaştıkları güçlükler. Yayımlanmamış Yüksek Lisans Tezi, Sosyal Bilimleri Enstitüsü, Selçuk Üniversitesi, Türkiye.

Qirim, N (2011). Determinats of interactive white board success in teching in higher education institution, Computers \&Education, 56, 827-838.

Mentiş-Taş, A. (2004). Sosyal bilgiler öğretmenliği eğitimi program standartlarının belirlenmesi. Ankara Üniversitesi Eğitim Bilimleri Fakültesi Dergisi, 37(1), 28-51.

Ministry of National Education (MoNE). (2017). Milli eğitim bakanlığı FATïH Projesi. Retrieved from http://fatihprojesi.meb.gov.tr.

Pamuk, S., Çakır, R., Ergun, M., Yılmaz, H. B. \& Ayas, C. (2013). The use of tablet PC and interactive board from the perspectives of teachers and students: evaluation of the FATIH project. Educational Sciences: Theory \& Practice, 13(3), 1815-1822. DOI: 10.12738/estp.2013.3.1734

Sağlam, F. (2007). İlköğretim okullarında görev yapan öğretmenlerin derslerinde bilgi teknolojisi kaynaklarından yararlanma öz-yeterlikleri ve etki algllarının değerlendirilmesi. Yayımlanmamış Yüksek Lisans Tezi, Yeditepe Üniversitesi, İstanbul.

Starkings, S. \& Krause, L. (2008).Chalkboard to smartboard-maths going gren? MSOR Connections, 7(4), 13-15.

Şad, S. N. (2012). An Attitude scale for smart board use in education: validity and reliability studies. Computers \& Education, 58(3), 900-907. 
Şensoy, Ö. (2004). BDÖ deneyimi olan öğretmenlerin bilgisayar öz-yeterlik algiları ve BDÖ yönteminin yararına ilişkin inançları üzerine bir çalışma. Yayınlanmamış Yüksek Lisans Tezi. Yıldız Teknik Üniversitesi, İstanbul.

Taşlıbeyaz, T. (2010). Ortaöğretim öğrencilerinin bilgisayar destekli matematik öğretiminde matematik algılarına yönelik durum çalışması: Lise 3.sinıf uygulaması. Yayımlanmamış Yüksek Lisans Tezi, Eğitim Bilimleri Enstitüsü, Atatürk Üniversitesi, Erzurum.

Yalçınkaya, Y. \& Özkan, H. H. (2014). Ortaöğretim öğretmenlerinin etkileşimli tahta kullanımına yönelik öz yeterlikleri. Mehmet Akif Ersoy Üniversitesi Eğitim Fakültesi Dergisi, 29, 6991.

Yalçınkaya, Y. (2013). Ortaöğretim öğretmenlerinin etkileşimli tahta kullanımına yönelik öz yeterlikleri. Yayımlanmamış Yüksek Lisans Tezi, Süleyman Demirel Üniversitesi, Isparta.

Zengin, F.K., Kırılmazkaya, G. \& Keçeci, G. (2011). Akıllı tahta kullanımının ilköğretim öğrencilerinin fen ve teknoloji dersindeki başarı ve tutuma etkisi. 5th International Computer \& Instructional Technologies Symposium, 27702-27707.

\section{Biographical Statements}

Mehmet Tamer KAYA is a research assistant in social studies at the University of Afyon Kocatepe. His research interests focus on social sciencies education.

Hakkı YAZICI is a professor in geography education at the University of Afyon Kocatepe. His research interests focus on teacher education and geographical education. 